\title{
A MULTIMODAL DISCOURSE ANALYSIS OF FAST FOOD ADVERTISEMENTS IN ENGLISH
}

\author{
Nguyen Trong Du', Duong Hong Yen ${ }^{2 *}$, Nguyen Thi Phuong ${ }^{1}$ \\ ${ }^{1}$ Thai Nguyen University, ${ }^{2} T N U-$ School of Foreign Languages
}

\section{ABSTRACT}

Online advertisement is one of the various kinds of media advertisement which unavoidably surrounds people's life these days. This paper presents the major findings of a recent study aiming at figuring out which verbal and non-verbal elements have been used in fast food ads in English and how effective they are on the consumption of the audience. The study drew on the Multimodal Interactional discourse analysis (Norris, 2004) as both theoretical and analytical framework. Two video ads of two well-known fast food chains in the world (Kentucky Fried Chicken andMcDonald's) were analyzed. The findings of the study reveal that apart from language, there are many other communicative modes influencing people to consume fast food products such as proxemics, posture, gesture, gaze, head movement, music, print, and layout. Each mode weighs differently in the ads and has certain effects in persuading ad viewers.

Keywords: Advertisement; fast food; verbal and non-verbal elements; multimodal discourse analysis; communicative mode.

\section{PHÂN TÍCH DIẼ̃N NGÔN ĐA PHƯƠNG THỨC NHŨ̉NG QUẢNG CÁO ĐỒ ĂN NHANH BẦNG TIẾNG ANH}

\author{
Nguyễn Trọng Du ${ }^{1}$, Dương Hồng Yến ${ }^{2 *}$, Nguyễn Thị Phượng ${ }^{1}$ \\ ${ }^{1}$ Đại học Thái Nguyên, ${ }^{2}$ Khoa Ngoại ngũ - ĐH Thái Nguyên
}

\section{TÓM TẮT}

Quảng cáo trực tuyến là một trong số những loại hình quảng cáo truyền thông mà con người thường xuyên tiếp xúc trong thời đại hiện nay. Mục đích của bài báo là tìm ra các yếu tố ngôn ngữ và phi ngôn ngữ đã được sử dụng trong quảng cáo thức ăn nhanh bằng tiếng Anh và tác dụng thuyết phục của chúng đối với việc tiêu thụ sản phẩm của người xem. Nghiên cứu này áp dụng mô hình phân tích diễn ngôn đa phương thức (Norris, 2004) làm cơ sở lý thuyết và đường hướng phân tích. Qua phân tích hai video quảng cáo của hai chuỗi thức ăn nhanh nổi tiếng thế giới (Kentucky Fried Chicken và $\mathrm{McDonald}$ ), kết quả của nghiên cứu cho thấy ngoài ngôn ngữ, còn có nhiều phương thức giao tiếp khác ảnh hưởng đến việc tiêu thụ các sản phẩm thức ăn nhanh như khoảng cách không gian, tư thế, cử chỉ, ánh mắt, chuyển động đầu, âm nhạc, in ấn và bố cục. Mức độ ảnh hưởng của mỗi phương thức trong từng quảng cáo là khác nhau và có tác dụng nhất định trong việc thuyết phục người xem.

Từ khóa: Quảng cáo; thức ăn nhanh; yếu tố ngôn ngũ và phi ngôn ngũ;; phân tích diễn ngôn đa phuoong thức; phương thức giao tiếp.

Ngày nhận bài: 10/5/2019; Ngày hoàn thiện: 24/7/2019; Ngày đăng: 05/8/2019

\footnotetext{
* Corresponding author. Email: yendh@tnu.edu.vn

DOI: https://doi.org/10.34238/tnu-jst.2020.03.1322
} 


\section{Introduction}

There is little doubt that advertising plays a crucial role in all kinds of business. Individuals can easily find advertisements anywhere. Over the last few decades, advertising has become extremely popular with a wide diversity in its forms. These days, advertising and promotion have exceeded their popularity beyond traditional media dominating last century like newspaper, magazines, radio or television. In accordance with the rapid development of information technology, online adverts seem to be more preferred due to its merits such as time saving, convenient [1]. Additionally, Chang and Thorson [2] found that the advertising on Television and Web could attract in higher attention, higher trust in perceived message and customers will have more positive thought than the effect of repetition in the use of single medium. Advertisement is a powerful tool of communication to persuade people to buy the product advertised [3] because it plays an important role in expressing and sending message of the product. Advertisement, in a simple word, means drawing attention to something or notifying something to somebody [3]. As a result, manufacturers see advertisements as a key tool to bring their products to the customers and to spread them worldwide.

Many fast food companies are very successful although the quality of their food is questioned every day in many research works and documentaries. It seems that they are willing to spend a lot of their budgets on advertising. In order to make their fast food products appeal to the viewers, the corporations must find the best ways to advertise. Interestingly, other semiotic resources besides language begin to be used more frequently and widely. Paltridge [4] argued that we have hardly ever seen a single use of one method of communication when interacting with each other, including through advertisements.
Also, Cook [5] explained that advertisements are compilation of different elements and these elements are interrelated to each other. There have been some research on food advertisements all over the world [6], [7]; however, virtually little attention has been paid to multimodal analysis of fast food advertisements. Hence, a multimodal interactional discourse analysis study of videos of fast food adverts will probably bring about a comprehensive look at the advertising discourse of fast food products.

The study aimed 1) to analyze discourse features of fast food advertisements in the perspective of multiple modes of communication including both linguistic and non-linguistic semiotic resources to achieve the best persuasion effects; 2) to see how different modes of communication are combined together in the advertisements to achieve the purposes of the fast food corporations.

\section{Methodology}

\subsection{Data source}

The data of the study include two video advertisements of two world famous fast food brands (KFC and McDonald's), each of which lasts about 30 seconds. They were published on the website www.youtube.com in 2015 and 2018. These ads are related to such types of fast food as fried chicken and burger.

\subsection{Data analysis method}

This study employed qualitative approach to the multimodal discourse analysis, which, in particular, applied the Multimodal interactional analysis (hereinafter called MIA for short) framework proposed by Norris [8] as its primary analytical tool.

MIA, which grew out of mediated discourse analysis (Scollon, [9] and Kress and van Leeuwen's early thoughts on multimodality [10]), has evolved into a firm methodology with a multitude of heuristic tools and strong theoretical underpinnings. It systematically examines multiple communication modes as cues to meaning rather than privileging language as the primary mode [8]. 
Multimodal discourse analysts see discourse as involving multiple modes, which often work together. For instance, in a face-to-face conversation people do not just communicate with spoken language. They also communicate though their gestures, gaze, facial expressions, posture, dress, how close or far away they stand or sit from each other, and many other things. Similarly, written texts rarely consist only of words, especially nowadays; they often include pictures, charts or graphs. Even the font that is used and the way paragraphs are arranged on a page or screen can convey meaning.

The point of MIA is not to analyze these other modes instead of speech and writing, but to understand how different modes, including speech and writing work together in discourse.

According to Norris [8], MIA is a holistic methodological framework that allows the analyst to integrate the verbal with the nonverbal, and to integrate these with material objects and the environment. MIA takes an interaction, grapples with its verbal and nonverbal language, and seeks to understand how they are interwoven and overlapping throughout the interaction. MIA, in other words, focuses not only on language but also on reading distinct types of nonverbal language, defined as "communicative modes" and determining how they link together as smaller pieces of action, or "lower-level actions", to create a larger communication chain or "higher level action" ([8], p. 11).

According to Norris [8], in addition to language, the communicative modes include the following things:

\section{Proxemics}

Proxemics is the ways we arrange our space in relation to other objects and/ or people.

\section{Posture}

Posture is the study of the ways in which individuals position their bodies.

\section{Gesture}

A gesture is a deliberately expressive movement that has a sharp boundary of onset.

\section{Head movement}

Head movement is the study of the ways that individuals position their heads.

\section{Gaze}

Gaze is the organization, direction, and intensity of looking.

Music

Mode of music refers to the music that appears in the interaction.

\section{Print}

The communicative mode of print refers to written texts, including the language, the medium, the typography, and the content when it is incorporated into the interactions.

Layout

The communicative mode of layout refers to the setting and the objects found within it.

In addition, according to Norris [8], in order to analyze data in the perspective of MIA, it is important for analysts to understand the following concepts and consider them when analyzing.

\section{Embodied vs disembodied modes}

Apart from language, other communicative modes such as gaze, gesture, posture could play equal role or even superordinate role in a lot of interactions and those are call embodied modes. In contrast, disembodied modes are the ones of the setting or material world that people use in the interactions as music, print, and layout. These modes can become embodied modes when they take superordinate role in the interactions.

Lower-level actions, higher level actions, and frozen actions

A lower-level action is the smallest interactional meaning unit whereas a higherlevel action bracketed by an opening and a closing of the meeting and is made up of a multiplicity of chained lower-level actions. Frozen actions are the ones which were performed by someone at an earlier time than the real time of the interactions being analyzed. These actions are frozen in the material objects and the environment.

Modal density, modal intensity and modal complexity

According to Norris [8], modal density refers to the modal intensity and/or the modal complexity through which a higher-level action is shaped. 
The intensity, weight, or importance of specific modes in interaction is decided by the situation, the social actors, and other related social and environmental factors. Hence, the weight of any specific mode varies from one interaction to the next or even within an interaction. Modal complexity refers to the interplay of multiple communicative modes utilized in the interaction.

Attention vs awareness

A person may simultaneously engage in a few higher-level actions on different levels of attention and awareness.

\section{Foreground-background continuum}

Foreground-background continuum represents the various degrees of attention that an individual is simultaneously engaged in interaction.

\section{Analysis and discussion}

\subsection{KFC advert}

Name of video advert: KFC | Country Music Singer [12]

Published date: 25 January 2018

Length: 30 seconds

Interaction: Musical performance

Participants: an American country music female singer (Reba Nell McEntire); a music band including four members playing instruments

Food: smoky Mountain BBQ (Barbecue fried chicken)

\section{Description}

In the first part of the video, the main participant - Reba singer that KFC hired for the ad- sings a song in which the lyrics are about the new BBQ chicken - smoky mountain BBQ. Then she changed her clothes and appears in the image of the legendary KFC salesman - the founder of KFC - Colonel Harland Sanders. Finally, the video ends with the information advertised the food together with its price.

\section{Analysis and discussion}

In the video, the main participant performs the foregrounded higher level action of singing which are co-constructed by the modes of spoken language, proxemics posture, gesture, gaze, head movement, music (embodied), print, and layout.
The images in the first three rows of the Figure 1 (from 0:00.5 to 0:12.76) depict the multiple modes that she uses to perform the action of singing when being appeared as Reba country music singer. Visible in the first snapshot, she is standing, holding a microphone in her right hand to sing, and lifting her left hand upwards. She takes longer distance with other participants - the band around her - than the table of KFC fast food next to her. These distances were predetermined by her actions of singing and marketing for KFC. She does not need to stand or sit near the members of the band to perform the action of singing while in order to advertise the foods she should position herself closer to the table to be able to touch them. The setting of the advert is in a jungle, which is rarely seen in fast food adverts. This setting could bring to the ad viewers a fresh atmosphere and help them enjoy the music. The mode of head movement also involves when the singer shakes her head several times as shown in the images at 0:04.12 and $0: 05.20$. It indicates that she is enjoying the music very much. Hereby, the viewers may feel relaxed when watching the performance. Also, when combining this with the lyrics and the piece of fried chicken she is holding, it can be interpreted that she would like to show the audience that the food is very delicious. Therefore, she not only attracts the audience to watch her performance but also encourages them to buy KFC product. The music is country music (the kind of music which Reba singer is well-known for) with special lyrics staring with the name of the target product followed by some positive adjectives to describe it: "smoky mountain barbecue fried chicken so crispy and sweet. That fried crispy chicken...". The language here is very important because without it we cannot understand what the piece of song is about; therefore, it takes on high intensity in the interaction. However, when there is an image of the fried chicken appeared as illustrated in the second picture in the second row of the figure, the role of language has decreased. 
Viewers can somehow know about the product by just looking at it as well. After the singer asks the band to stop the music for a while and change her clothes (from images at $0: 11.08$ to $0: 12.76$ ), she continues singing "...sell my delicious new smoky mountain barbecue" but this time she holds a piece of fried chicken instead of a microphone. This action enables the viewers to get the most important message from the advertiser - to promote the new fried chicken product of KFC. Beside necessary objects for a musical performance such as a micro, instruments like drums, guitars, and violin, there are some objects that are used in the video to communicate their own meanings (see from images at $0: 13.47$ to $0: 29.86$ ). Firstly, the set of clothes including white suit, glasses and related accessories that the salesman (Reba singer disguised) is wearing is actually a typical KFC brand image (image at 0:13.47). It depicts the owner of the food chain, Colonel. Secondly, the table on which the smoky mountain BBQ displayed is set next to the salesman so that the person can pick it up more easily (images at 0:09.38 and 0:19.20). Here we could interpret that there are some frozen actions completed as making the fried chicken and putting them on the table instead of showing how and the process to make the fast food because maybe the company would like to hide the secret of making the food.

As for the mode of print, it can be seen that the name of the target product "KFC smoky mountain BBQ" appeared throughout the video (almost images of Figure 1). In the very last part of the ad, the whole image of the food is shown together with its name and price as revealed in the image at 0:29.86. It helps emphasize KFC brand name.

In summary, in this advert the advertiser would like to introduce the target fast food through the higher level action of singing. This action can only be constructed with music, utilizing music as an embodied mode. The mode of music, therefore, takes on high intensity. The modes of print and layout have big impacts on targeting the audiences at the
KFC product. Spoken language (lyrics in this case) is also important. However, if it is removed, the viewers can still understand the purpose of the advertiser for the product by the end of the clip. The main participant utilizes proxemics, head movement, gaze, posture, gesture rather intensely but if they are changed in some ways or taken away, the action of singing would still be possible. It cannot be denied these modes take somewhat modal intensity for the singer to have her best performance but they are not as intense as the mode of spoken language in the first part of the ad and mode of music.
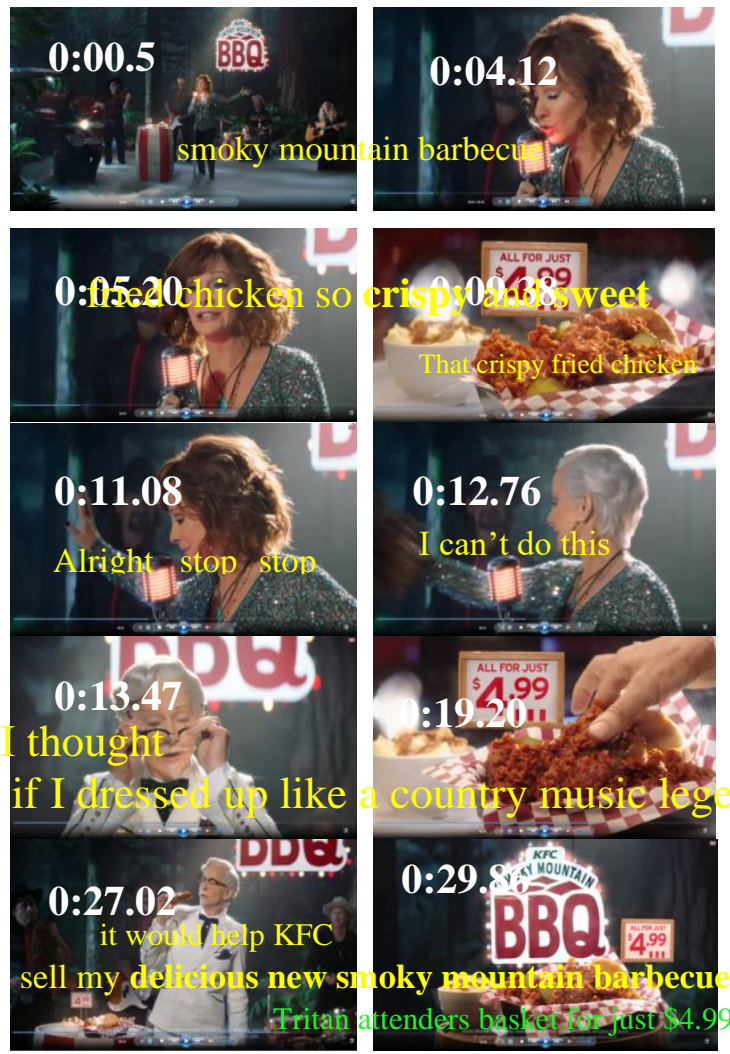

Figure 1. Full multimodal transcript of KFC ad

\subsection{McDonald's advert}

Name of video advert: Best ever McDonalds

"My Dad" TV Advert - June 2015 [12]

Published date: 9 June 2015

Length: 30 seconds

Interaction: having a meal

Participants: dad, son

Food: Barbecue chicken legend deluxe (Burger) 


\section{Description}

The dad and son sit indoors. It is probably the place in which the kind of food is served. The son talks to himself in his thoughts about how he would make his daily chicken sandwich. Then, he mentions different ingredients to make that food together with their illustrations. Next, he passes the burger to his dad with a smile and the father smiles back without saying a word. The images of the food, the logo and slogan come up at the end of the advertisement.

\section{Analysis and discussion}

The first image in Figure 2 shows the boy sitting, looking intently at something or someone opposite. He thinks in his mind about making "daily chicken sandwich" and then lists the ingredients as visible in the images at 0:05.29 to 0:13.88. If the words in his mind are not transcribed, viewers can still somehow guess what he is thinking about thanks to the vivid illustrations of the ingredients (chicken, bacon, lettuce, cheese, sauce, bun). So, verbal behavior takes on no intensity for the two actors and somewhat intensity for the audiences. The still image at $0: 16.35$ starts to reveal the person who is gazing towards his father, the proximity they take, their posture, gesture, head positions, the setting, etc. They are sitting face-to-face at a dining table inside a restaurant and the son is going to perform the action of passing a burger to his dad. The boy takes up shorter distance to the hamburger so that he could touch it easily. This proximity makes the interaction between the participants possible. Imagine if they changed their seats to sit next to each other to one side, it would be difficult for both to observe the other partner and perform the actions they want; therefore, the proxemics mode in this case takes on high intensity in interaction.

Then, they both look at the burger on the table (as in image at 0:17.60) before the son passes it to his daddy (image at 0:18.51.). It means that both of them are highly aware of and attentive to the on-going interaction After that, they give each other mutual gaze and smile happily. As illustrated in the figure, the two participants communicate their perceptions, thoughts, and feelings mainly through their gestures and gazes without spoken language while head movement, which changes according to those modes, plays a subordinate role for the other modes. They still understand what the other person wants to say and show their emotions accordingly.

The last image of the figure at 0:23.40 shows the logo and slogan of McDonald's company. It helps emphasize the trademark.
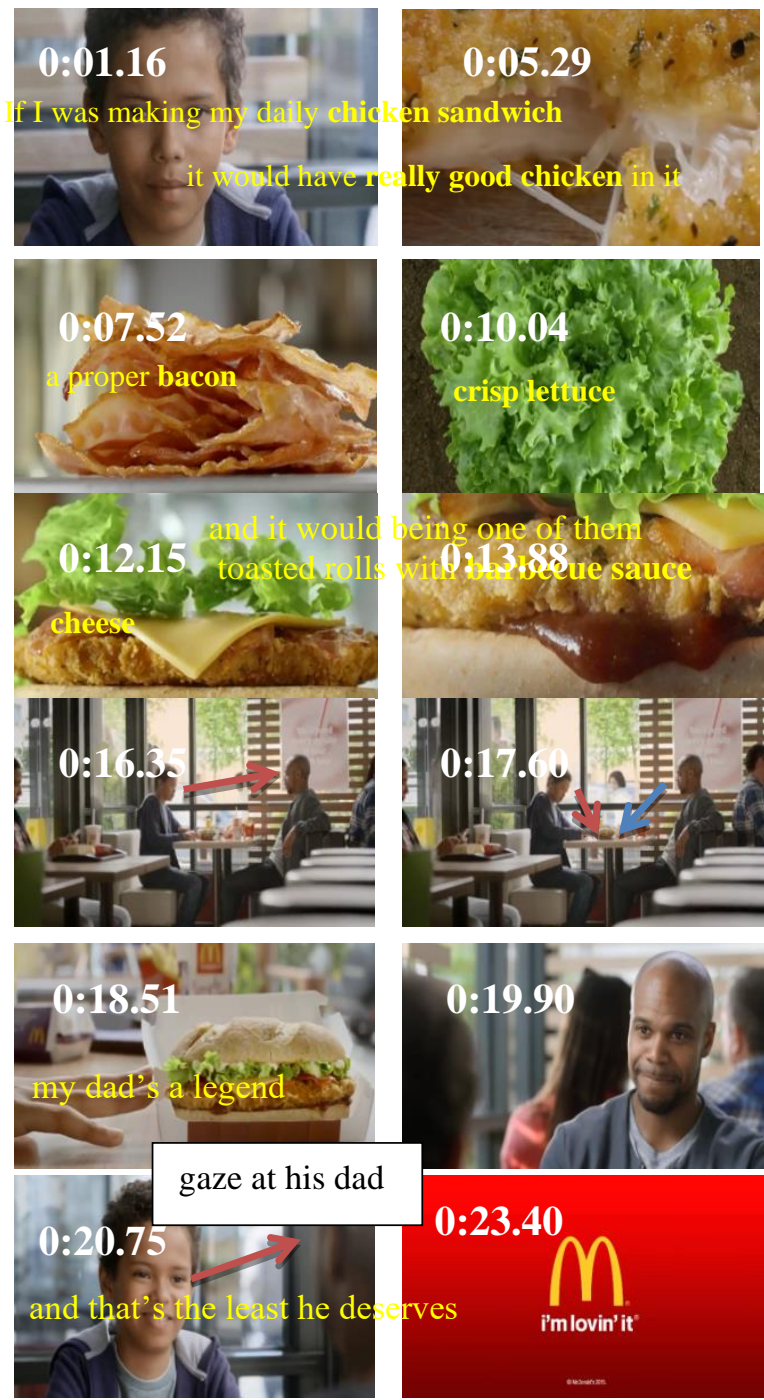

Figure 2. Full multimodal transcript of McDonald's ad 
As we know, in a lot of interactions, language often plays primary role in conveying messages; however; here, there is no verbal conversation between the two actors in the advert but the interaction is still on-going by various communicative modes. Thus, rather than looking at posture, gesture, head movement and gaze as an appendix to language and viewing language as the central mode, language in this interaction takes on no particular intensity for the participants and for the viewers it is simply a part of meaningmaking aggregate. The son uses posture, gesture, head movement and gaze to communicate with his father, which is only possible through his use of the modes of layout and proxemics. The mode of print provides more information for the sale of the fast food product and highlights the McDonald's brand name. These modes are tightly interconnected and together send a coherent message. Among these modes, gaze is a very necessary component for the son, which follows his action of passing the burger and observes his dad's reaction. For the dad, gaze is also crucial because he cannot know what is going on without seeing in his own eyes. Therefore, gaze takes on high intensity in the interaction. In addition to all the modes above, facial expression should not be missed to mention. It helps express the participants' feelings, which in this advert possibly are love and satisfaction, without language. In short, it could be implied from the ad that giving McDonald's chicken sandwich to someone you adore is one of the ways to express how much you love them. As a result, McDonald's would attract more customers come to buy their fast food.

\section{Conclusion}

To conclude, by analyzing two advert videos of the two well-known fast food brands (KFC and McDonald's), the linguistic and nonlinguistic features utilized have been pointed out: spoken language, proxemics, posture, gesture, gaze, head movement, music, print and layout. These modes are interconnected to one another to convey messages from the producers to the customers, and the employment of one mode is not possible without at least some others. Their roles, however, could be at different levels of significance. In other words, as Norris defined [8], they take different levels of intensity in interactions. However, it could be some modes, not all of the modes appeared in one advertisement. By looking closely at the sample videos, it could be interpreted that language in fast food advertisements, unlike in other situations, generally is not always the only and primary communicative means meanwhile music, gaze, print, and layout are also shown to play crucial roles in transferring meanings as well as attracting the audiences.

Regarding effects that linguistic and nonlinguistic features in fast food advert videos, it could be concluded from the findings that all communicative modes emerged in the ads support one another in order to reach the audiences' eyes, ears and emotions. This is a lot different from adverts on radio or newspaper in which one mode may dominate other modes. By combining various communicative modes in advert videos, the producers could express the best of their products in interesting and entertaining ways.

As for some implications of the study, in the first place, the researcher believe that the study contributes to enrich the existing literature of discourse analysis on fast food advertisements, especially basing on multimodal interactional discourse analysis which could not be seen in the majority of studies on advertising. Hence, this research is expected to severe as a helpful reference for students majoring in English language of English language researchers when they study fast food advertisements. 
Furthermore, the results of the study could be beneficial in teaching and learning English language as well. English learners who desire to master English language, especially English conversations, should not only pay attention to learn the language only. Similarly, teachers of English should be reminded to combine considering other communicative features such as proxemics, posture, gesture, gaze, head movement, music, print, and layout rather than linguistic feature only in understanding and teaching conversational English.

\section{REFERENCES}

[1]. Y. Chang and E. Thorson, "Television and web advertising synergies," Journal of Advertising, vol. 33, no. 2, pp. 75-84, 2004, doi: 10.1080/00913367.2004.10639161.

[2]. Y. Chang and E. Thorson, "Television and web advertising synergies," Journal of Advertising, vol. 33, no. 2, pp. 75-84, 2004.

[3]. G. Dyer, Advertising as Communication. London: Routledge, Clays Ltd, St Ives Pic, 1996.

[4]. B. Paltridge, Discourse Analysis: An Introduction. London and New York: Bloomsbury Publishing, 2012.
[5]. G. Cook, Discourse of Advertising. New York, NY: Routledge, 2001.

[6]. T. C. H. Nguyen, "A Discourse Analysis of the Linguistic Features of the Advertisements of Food and Drink in English versus Vietnamese," M.A. Thesis, Da Nang University, 2011.

[7]. V. Schmidtová, "Fast Food Advertising: Discourse Analysis," Bachelor Thesis. Brno: Masaryk University, Faculty of Education, Department of English Language and Literature. Supervisor: Mgr. Martin Adam, $\mathrm{PhD}, 2014$.

[8]. S. Norris, Analyzing multimodal interaction: A methodological framework. New York: Routledge, 2004

[9]. R. Scollon and S. W. Scollon, Discourses in Place: Language in the Material World. London: Routledge, 2003.

[10]. G. Kress and T. Leeuwen, Reading Images: The Grammar of Visual Design. London, Routledge, 1996.

[11]. M. Judd, "KFC Commercial: Country Music Singer", January, 2018. [Online]. Available:https://www.youtube.com/watch? $\mathrm{v}=\mathrm{qHX14Zi98Zc.} \mathrm{[Accessed} \mathrm{March} \mathrm{18,} \mathrm{2019].}$

[12]. J. MysTycal, "BEST EVER McDonalds 'My Dad' TV Advert", June 2015. [Online]. Available: https://www.youtube.com/watch? $\mathrm{v}=7 \mathrm{sVNsS5gR7k}$. [Accessed March 18, 2019]. 